\title{
The Impacts of Oil Price and Exchange Rate on Vietnamese Stock Market*
}

\author{
Tra Ngoc NGUYEN ${ }^{1}$, Dat Thanh NGUYEN ${ }^{2}$, Vu Ngoc NGUYEN ${ }^{3}$ \\ Received: May 24, 2020 Revised: June 07, 2020 Accepted: July 03, 2020
}

\begin{abstract}
This study aims to investigate the effect of oil price and exchange rate on the two Vietnamese stock market indices: VN index and HXN index. This study uses the daily data from August $1^{\text {st }} 2000$ to October $25^{\text {th }} 2019$ of the two Vietnamese stock indices: VN index and HNX index, the two oil price indices: BRENT and WTI, and the two exchange rates: US dollar to Vietnamese dong and Euro to Vietnamese dong. Due to the presence of heteroskedasticity in our data, we use GARCH $(1,1)$ regression model to perform our analysis. Our findings show that the oil price has a significant positive effect on the two Vietnamese stock market indices. In terms of the stock index volatility, both the VN index and HNX index volatilities are negatively impacted by the return of oil price. While the conclusion about the impact of oil price remained consistent through all three robustness tests, the effect of exchange rate on Vietnamese stock market indices is not consistent. We find thatchanges of the USD/VND exchange rate significantly impact the return and volatility of HNX index only in GARCH $(1,1)$ setting. Our analysis also survives a number of robustness tests.
\end{abstract}

Keywords: Stock Market Index, Oil Price, Exchange Rate, GARCH, Volatility

JEL Classification Code: C32, F31, G15

\section{Introduction}

The stock market index is always a great concern of both policymakers and investors all over the world. Practically, the links between some key index such as oil price and exchange rate have been deemed significant due to their important role in the development of economy. Therefore, understanding the relationships between these variables and the stock market index assists investors in making investment decisions and helps policymakers in designing policies in order to maintain the market stabilization. The aim

\footnotetext{
*Acknowledgements:

This research was funded by Vietnam Ministry of Education and Training under project number B2019-DNA-08.

${ }^{1}$ First Author. The University of Danang - University of Economics, Danang, Vietnam. Email: trann@due.udn.vn

${ }^{2}$ Corresponding Author. The University of Danang - University of Economics, Danang, Vietnam [Postal Address: 71 Ngu Hanh Son Street, Danang, 550000, Vietnam] Email: datnt@due.udn.vn ${ }^{3}$ The University of Danang, Danang, Vietnam. Email: nnvu@ac.udn.vn

(c) Copyright: The Author(s)

This is an Open Access article distributed under the terms of the Creative Commons Attribution Non-Commercial License (http://Creativecommons.org/licenses/by-nc/4.0/) which permits unrestricted noncommercial use, distribution, and reproduction in any medium, provided the original work is properly cited.
}

of this paper is to examine the effects of the crude oil price and exchange rate on Vietnamese stock indices, namely, VN index and HNX index. Our analysis employs a daily data including 7,025 observations, ranging from August $1^{\text {st }} 2000$ until October $25^{\text {th }} 2019$.

Our study relies on two strands of literature, the first is the relationship between exchange rate and stock market and the second is the relationship between oil price and stock market. The relationship between exchange rate and stock market has been a topical subject of previous literature. However, the diverse results from previous studies show no consensus on the relationship between exchange rate and stock market. Early research by Aggarwal (1981), and Giovannini and Jorion (1987) show a negative relationship between exchange rate and stock return in the U.S. Ajayi and Mougoue (1996) shows that currency depreciation has a negative short-run and long-run effect on stock market. Similarly, Kim (2003) found a negative relationship between the return of S\&P500 and the dollar exchange rate. Chiange et al. (2000) discovered that exchange rate is negatively related to several Asian stock markets by using bivariate GARCH model. The same pattern was also found in India by Agrawal (2010) and in Nigeria by Olugbenga (2012). Also, Lee and Zhao (2014) found negative long-run and short-run causality from exchange rate to the prices of Chinese stock market. 
In contrast, there are also studies that show a positive relationship between the exchange rate and stock return. Ibrahim and Aziz (2003) discovered a positive relationship between Malaysian stock prices and exchange rates in Malaysia over the period 1977-1998. Kurihara (2006) found a positive relationship between exchange rate and stock return when examined their relationship during the Quantitative Easing Policy 2001-2006 in Japan. Narayan and Narayan (2010) investigate the impact of oil price and exchange rate on Vietnam stock price. They found that exchange rate has a significant positive effect on stock prices in the long run. Lee and Brahmasrene (2019) also found that exchange rate (Korean Won/USD) is positively related to Korean stock prices.

In addition, other studies suggest that there is no significant relationship between exchange rate and stock return. Nieh and Lee (2001) did not find long run relationship between exchange rate and stock in the G7 countries. Smiech and Papiez (2013) studied the causality between fossil fuel prices, exchange rate and stock market and found no significant causal relationship between exchange rate and stock return. However, Wallid et al. (2011), using Markov switching EGARCH model, suggested that the relationship between the two variables are regime dependent, and so it can change between different periods.

Another strand of the literature deal with the volatility transmission between exchange rate and stock market. Most studies confirm the volatility interaction between the two markets. Yang and Doong (2004) analyzed the volatility transmission between stock market and exchange rate for G7. They employed the EGARCH model and find significant volatility spillover from stock market to the exchange rate while the opposite transmission was faint. Aloui (2007) came to the same conclusion for the US and EU market. By employing the MGARCH model, Zhao (2010) finds bidirectional volatility spillovers between exchange rate and stock market in China. Phan et al. (2015) find that the price volatility of exchange rate can be used to predict the volatility of stock market and vice versa.

Besides exchange rate, the effects of oil price on stock market has been extensively studied such as Basher and Sadorsky (2006), Narayan and Narayan (2010), Aloui et al. (2013), Echchabi and Azouzi (2017), Youssef and Mokni (2019) and Nguyen and Nguyen (2020). ${ }^{i}$ Basher and Sadorsky (2006) investigated 21 emerging markets and find the relationship between oil and stock to be positive. A study by Aloui et al. (2013) also finds a positive correlation between oil and stock for six Central and Eastern Europe countries. Echchabi and Azouzi (2017) found that oil price fluctuations significantly impact the prices of Omani stock market while movements in stock market don't affect oil prices. More recently, Youssef and Mokni (2019) studied the impact of oil shocks on the stock market of both oil-importing and exporting countries using the DCC-FIGARCH. They find the responses of stock markets to oil price shocks are time-varying and positive for both oil-importing and exporting countries. Nevertheless, the impact of oil shocks is higher in oil-exporting countries. In the case of Vietnam, Narayan and Narayan (2010) find that oil, exchange rate and stock market are cointegrated. Nguyen and Nguyen (2020) showed that crude oil price can be very useful in forecasting the Vietnamese stock market return.

Our study contributes to the literature in some important directions. First, we extend the literature examining the impacts of oil price and exchange rate on emerging stock market, i.e., Vietnam. Although a number of studies has been done on these relationships, there are only a few papers that address the impacts of both oil price and exchange rate, for example, Narayan and Narayan (2010), Smiech (2013) and Jain and Biswal (2016). Second, Vietnam is an interesting example. This country is different from the other emerging economies as it adopts a fixed exchange regime, and both exports and imports oil at the same time. Therefore, it is important to investigate the effect of oil price and exchange rate on Vietnamese stock market index.

Due to the presence of heteroskedasticity in our data, we employ the GARCH $(1,1)$ model to analyze the effect of oil price return and exchange rate return on Vietnam stock index return and volatility. The analysis shows that historical oil price has a significant positive effect on the two Vietnamese stock market indices, VN index and HNX index. In term of the stock index volatility, we find that both the $\mathrm{VN}$ index and HNX index volatilities are negatively impacted by the return of oil price. Differently, exchange rate return exhibits negative effects on stock index returns and positive effect on the volatility of VN index and HNX index returns. We also employ some robustness tests, namely: (1) different oil price and exchange rate; (2) different model specification, i.e. EGARCH $(1,1)$; and (3) different sub-sample.

The remainder of this paper proceeds as follows. The next section describes our data and empirical model. Section III presents the findings from our main results as well as those from robustness tests. Finally, we provide concluding remarks in the last section.

\section{Data and Methodology}

\subsection{Data}

Table 1 provides descriptions of all the variables used in this research. All specific data were downloaded from Investing.com database. Our sample data is at daily frequency and starts from August $1^{\text {st }} 2000$ and end on October $25^{\text {th }}$ 2019. Finally, we end up with 7,025 observations, except for the HNX index return, which has only 5,213 observations as the index was introduced on July $18^{\text {th }} 2005$. 
Table 1: Variables description

\begin{tabular}{|l|l|}
\hline Variable & \multicolumn{1}{c|}{ Description } \\
\hline$R^{V N I}$ & VN index return \\
\hline$R^{B R E N T}$ & Brent oil futures price return \\
\hline$R^{U S}$ & $\begin{array}{l}\text { US Dollar to Vietnamese Dong exchange rate } \\
\text { return }\end{array}$ \\
\hline$R^{H N X}$ & HNX index return \\
\hline$R^{W T I}$ & WTI oil futures price return \\
\hline$R^{E U R}$ & $\begin{array}{l}\text { Euro to Vietnamese Dong exchange rate } \\
\text { return }\end{array}$ \\
\hline
\end{tabular}

\subsection{Methodology}

Following the previous literature, we separatemain regressionsin two following GARCH $(1,1)$ models:

$$
\begin{aligned}
R_{t}^{\text {Index }} & =\beta_{0}+\beta_{1} R_{t-1}^{\text {Index }}+\beta R_{t-1}^{\text {Indicator }}+\varepsilon_{t}, \\
\varepsilon_{t} & \rightarrow N\left(0, \sigma_{t}^{2}\right) \\
\sigma_{t}^{2} & =\omega_{0}+\gamma \varepsilon_{t-1}^{2}+\lambda \sigma_{t-1}^{2} ; \\
R_{t}^{\text {Index }} & =\beta_{0}+\varepsilon_{t} \\
\varepsilon_{t} & \rightarrow N\left(0, \sigma_{t}^{2}\right) \\
\sigma_{t}^{2} & =\omega_{0}+\omega_{1} R_{t-1}^{\text {Indicator }}+\gamma \varepsilon_{t-1}^{2}+\lambda \sigma_{t-1}^{2} .
\end{aligned}
$$

where, (1) is the estimation of stock index returns and (2) is the estimation of volatility of the stock index returns. $t$ is index time. $R^{\text {Index }}$ is our stock index returns, which are $R^{V N I}$ and $R^{H N X}$. $R^{\text {Indicator }}$ includes the return of BRENT oil price $\left(R^{B R E N T}\right)$ and the return of USD to VND exchange rate $\left(R^{U S}\right)$. For robustness tests, we use various approaches such as using different oil price and exchange rate, using EGARCH $(1,1)$ model and using after financial crisis subsample.

\section{Empirical Results}

\subsection{Preliminary Results}

Table 2: Summary statistics
First, the descriptive statistics are reported in Table 2. The main statistics include the number of observations, mean, median, maximum, minimum, standard deviation (SD), skewness, kurtosis, p-value of Jarque-Bera (JB) test, augmented Dickey-Fuller (ADF) test, autocorrelation $\mathrm{AR}(1)$ coefficient, and p-value of LM test for autoregressive conditional heteroskedasticity (ARCH). For stock market index returns, while the movements of VN index and HNX index are similar, there are slight differences in their mean return and volatility. On average, $\mathrm{VN}$ index daily return is higher, 0.0013, compares with 0.0012 , and less volatile than HNX index return. Similarly, there is also not much difference between BRENT and WTI oil price return. The average return of BRENT is $0.09 \%$, while the average return of WTI is $0.1 \%$, which is only $0.01 \%$ higher. The standard deviation of BRENT return is $2.12 \%$, which is marginally smaller than WTI standard deviation of $2.3 \%$. For exchange rate, while the average return of USD/VND and EUR/VND have the same value of $0.01 \%$, interestingly the EUR/VND return is almost three times more volatile than the USD/ VND return. The heterogeneity in various stock indices, oil prices and exchange rates support our approaches of using difference variables in examining the impact of them on Vietnamese stock market indices.

The results of the augmented Dicky-Fuller (ADF) tests show that all series are stationary. We also check the persistency of all variables by measuring their autoregressive AR(1) coefficients. The stock index returns are significantly more persistent than the other series. VN index and HNX index AR(1) coefficients are 0.537 and 0.418 , respectively, while none of the remaining series has an $\mathrm{AR}(1)$ coefficient higher than 0.30. Moreover, all index returnshave strong $\mathrm{ARCH}$ effect, which are shown by the p-value of autoregressive heteroskedasticity (ARCH) test reported in the last column of Table 2 .

Table 2 reports some descriptive statistics for VN index, Brent oil futures price, US Dollar to Vietnamese Dong exchange rate, HNX index, WTI oil futures price and Euro to Vietnamese Dong returns. The number of observations, mean, median, maximum, minimum, standard deviation (SD), skewness, kurtosis, p-value of Jarque-Bera (JB)

\begin{tabular}{|l|c|c|c|c|c|c|c|c|c|c|c|c|}
\hline & Obs. & Mean & Median & Maximum & Minimum & SD & Skewness & Kurtosis & JB & ADF & AR(1) & ARCH(1) \\
\hline$R^{\text {VII }}$ & 7025 & 0.0013 & 0.0010 & 0.0688 & -0.0737 & 0.0151 & -0.1886 & 6.5781 & 0 & -45.995 & 0.5370 & 0 \\
\hline$R^{B R E N T}$ & 7025 & 0.0009 & 0.0012 & 0.1461 & -0.1344 & 0.0212 & 0.1194 & 6.4239 & 0 & -66.512 & 0.2270 & 0 \\
\hline$R^{U S}$ & 7025 & 0.0001 & 0.0000 & 0.0672 & -0.0427 & 0.0022 & 13.0165 & 424.1069 & 0 & -66.140 & 0.2323 & 0 \\
\hline$R^{\text {HNX }}$ & 5213 & 0.0012 & 0.0005 & 0.1022 & -0.1207 & 0.0188 & 0.3452 & 7.9964 & 0 & -46.245 & 0.4180 & 0 \\
\hline$R^{W T I}$ & 7025 & 0.0010 & 0.0014 & 0.1783 & -0.1525 & 0.0230 & 0.2014 & 7.2958 & 0 & -65.952 & 0.2350 & 0 \\
\hline$R^{E U R}$ & 7025 & 0.0001 & 0.0002 & 0.0600 & -0.0382 & 0.0064 & 0.1447 & 5.9303 & 0 & -63.050 & 0.2773 & 0 \\
\hline
\end{tabular}


test, augmented Dickey-Fuller (ADF) test, autocorrelation AR(1) coefficient, and p-value of LM test for autoregressive conditional heteroskedasticity $(\mathrm{ARCH})$ are reported. The ADF unit root test is based on a model with an intercept but no time trend. The LM test for ARCH is based on a mean equation.

Next, we looking at Table 2 which reports the results of the following OLS regression:

$$
R_{t}^{\text {Index }}=\beta_{0}+\beta_{1} R_{t-1}^{\text {Index }}+\beta R_{t-1}^{\text {Indicator }}+\varepsilon_{t},
$$

where, $R^{\text {Index }}$ is our stock index return that is $R^{V N I}$ in the first three models and $R^{H N X}$ in the last three models. $R^{\text {Indicator }}$ includes the return of BRENT oil price and the return of USD to VND exchange rate.

There are two predictive regressions that are estimated based on the stock index returns, VN index and HNX index, and two predictors, BRENT oil price return and USD/VND exchange rate return. The results of the test for $\mathrm{ARCH}(1)$ effect are reported in the last row of Table 3. The preliminary results show that the return of BRENT oil price has positive impacts on the stock index return, both VN index and HNX index. In detail, one percentage point increase in oil price return leads to 0.0448 and 0.0777 increase $\mathrm{VN}$ index and HNX index respectively. In addition, the impact of oil price return is statistically significant at $1 \%$ level in both model specifications (I) and (II). However, the test results show both models exhibit heteroskedasticity, the test values are both significant at $1 \%$ level.Therefore, thestandard regressions should not be applied in this case. Instead, ARCH-type models should be used for further analysis.

Table 3 reports the regression results of oil price and/or exchange rate effect on Viet Nam stock index. The regression model takes the following form:

$$
R_{t}^{\text {Index }}=\beta_{0}+\beta_{1} R_{t-1}^{\text {Index }}+\beta R_{t-1}^{\text {Indicator }}+\varepsilon_{t},
$$

where, $R_{-}$Index is our stock index return, which is $R_{-} V N I$ in the first three models and $R_{-} H N X$ in the last

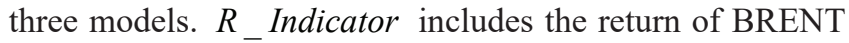
oil price and the return of USD to VND exchange rate. The coefficients and standard errors are reported. The LM test statistics for ARCH (1) effect of the residuals for each regression are also reported in the last row.

\subsection{Regression Results}

Due to the presence of heteroskedasticity, we employ the $\operatorname{GARCH}(1,1)$ model to analyze the effect of oil price return and exchange rate return on Vietnam stock index return and volatility.The estimation results for the mean and variance equations are reported in Table 4.Similar to the preliminary results, we find thathistorical oil price return
Table 3: Preliminary results

\begin{tabular}{|l|c|c|}
\hline & I & II \\
\hline Variables & $R_{t}^{V N I}$ & $R_{t}^{H N X}$ \\
\hline$R_{t-1}^{V N I}$ & $0.5336^{* * *}$ & $0.4133^{* * *}$ \\
\hline$R_{t-1}^{H N X}$ & & $0.0777^{* * *}$ \\
\hline$R_{t-1}^{B R E N T}$ & $0.0448^{* * *}$ & -0.0672 \\
\hline$R_{t-1}^{U S}$ & -0.0202 & $0.0007^{* * *}$ \\
\hline Constant & $0.0006^{* * *}$ & $506.075^{* * *}$ \\
\hline ARCH(1) & $344.682^{* * *}$ & \\
\hline
\end{tabular}

${ }^{*},{ }^{* *}$, and ${ }^{* * *}$ denote significance at the $10 \%, 5 \%$ and $1 \%$ levels, respectively.

can be a good predictor of stock index return and volatility. The results in Panel A of Table 4 show a significant positive effectof historical BRENT oil price return onthe two stock indices, VN index and HNX index. The effect of oil price is statistically significant at $1 \%$ for both VN index and HNX index. Specifically, one percentage point increase in BRENT oil price return associates with 2.24 percentage points increase in the return of $\mathrm{VN}$ index and 3.97 percentage points increase in that of HNX index. These resultsare consistent with previous studies by Basher and Sadorsky (2006), Narayan et al. (2010), Youssef and Mokni (2019), and Nguyen and Nguyen (2019). In term of the relationship between oil price return and stock index volatility, looking at Panel B of Table 4,we find that both the VN index and HNX index volatilities are negatively impacted by the return of oil price. In other words, an increase in oil price return reduces the volatility of the stock market indices. Moreover, the effect of oil price return on return and volatility is stronger with VN-index than with HNX-index. In conclusion, the oil price return is shown to have a positive effect of Vietnamese stock market indices, in term of both return and volatility.

Differently, exchange rate return shows significant negative correlation only with $\mathrm{HNX}$ index return at $1 \%$ confident level. One percentage point raise in USD/VND exchange rate return causes a 0.1197 percentage point drop in the HNX index return. As we use indirect quote, this result means an exchange rate depreciation has a negative impact on the stock index return. Regarding to the volatility of VN index and HNX index returns, exchange rate also has positive effect on both of these indices. The exchange rate coefficient is statistically significant at $1 \%$ in model (I) and $5 \%$ in model (II). This result is similar to what have been found by Nieh and Lee (2001), Gay (2008) or Zhao (2010). So, in contrast to the effect of oil price, the exchange rate is 
shown to have negative effects on both stock index returns and their volatilities.

Table 4 reports the GARCH $(1,1)$ regression results of oil price and/or exchange rate effect on Viet Nam stock index. The regression model takes the following form:

$$
\begin{aligned}
& R_{t}^{\text {Index }}=\beta_{0}+\beta_{1} R_{t-1}^{\text {Index }}+\beta R_{t-1}^{\text {Indicator }}+\varepsilon_{t}, \\
& \varepsilon_{t} \rightarrow N\left(0, \sigma_{t}^{2}\right), \\
& \sigma_{t}^{2}=\omega_{0}+\gamma \varepsilon_{t-1}^{2}+\lambda \sigma_{t-1}^{2} \\
& R_{t}^{\text {Index }}=\beta_{0}+\varepsilon_{t}, \\
& \varepsilon_{t} \rightarrow N\left(0, \sigma_{t}^{2}\right) \\
& \sigma_{t}^{2}=\omega_{0}+\omega_{1} R_{t-1}^{\text {Indicator }}+\gamma \varepsilon_{t-1}^{2}+\lambda \sigma_{t-1}^{2}
\end{aligned}
$$

where, $R_{t}^{\text {Index }}$ is our stock index return at time $t$, which is $R_{t}^{V N I}$ in the first model and $R_{t}^{H N X}$ in the second model. $R_{t-1}^{\text {Indicator }}$ includes the return of BRENT oil price and the return of USD to VND exchange rate at time $t-1$. Panel A reports the coefficients and standard errors of the mean equation in (1) and Panel B reports the coefficients and standard errors of the variance equation in (2).

Table 4: Estimation results

\begin{tabular}{|l|c|c|}
\hline & I & II \\
\hline $\begin{array}{l}\text { Dependent } \\
\text { variable }\end{array}$ & $R_{t}^{V N I}$ & $R_{t}^{H N X}$ \\
\hline Panel A: Mean equation in (1) \\
\hline$R_{t-1}^{V N I}$ & $0.4312^{* * *}$ & \\
\hline$R_{t-1}^{H N X}$ & & $0.2901^{* * *}$ \\
\hline$R_{t-1}^{\text {RRENT }}$ & $0.0224^{* * *}$ & $0.0397^{* * *}$ \\
\hline$R_{t-1}^{U S}$ & -0.0590 & $-0.1197^{* * *}$ \\
\hline Constant & $0.0003^{* * *}$ & $0.0006^{* * *}$ \\
\hline & $(0.0001)$ & $(0.0001)$ \\
\hline Panel B: Variance equation in (2) & \\
\hline$R_{t-1}^{\text {BRENT }}$ & $-15.3380^{* * *}$ & $-20.3508^{* * *}$ \\
\hline$R_{t-1}^{U S}$ & $50.0413^{* * *}$ & $36.6862^{* *}$ \\
\hline Constant & $-12.6373^{* * *}$ & $-12.4667^{* * *}$ \\
\hline
\end{tabular}

${ }^{*},{ }^{* *}$, and ${ }^{* * *}$ denote significance at the $10 \%, 5 \%$ and $1 \%$ levels, respectively. Note that all the ARCH and GARCH terms are not reported but they are significance at $1 \%$ level in all regressions.

\subsection{Robustness Tests}

We apply a number of different setups to see whether our baseline regression results are still applied. Particularly, we use three robustness tests, namely: (1) different oil price and exchange rate; (2) different model specification, i.e. EGARCH $(1,1)$; and (3) different sub-sample.

\subsubsection{Different Oil Price and Exchange Rate}

We examine the robustness of our previous findings by using different oil price and exchange rate. Instead of using the return of BRENT oil and USD/VND exchange rate, we perform the same estimation using WTI oil and EUR to VND exchange rate return as our exogenous regressors. The regression model takes the following form:

$$
\begin{aligned}
& R_{t}^{\text {Index }}=\beta_{0}+\beta_{1} R_{t-1}^{\text {Index }}+\beta R_{t-1}^{\text {Indicator }}+\varepsilon_{t}, \\
& \varepsilon_{t} \rightarrow N\left(0, \sigma_{t}^{2}\right), \sigma_{t}^{2}=\omega_{0}+\gamma \varepsilon_{t-1}^{2}+\lambda \sigma_{t-1}^{2} ; \\
& R_{t}^{\text {Index }}=\beta_{0}+\varepsilon_{t}, \varepsilon_{t} \rightarrow N\left(0, \sigma_{t}^{2}\right), \\
& \sigma_{t}^{2}=\omega_{0}+\omega_{1} R_{t-1}^{\text {Indicator }}+\gamma \varepsilon_{t-1}^{2}+\lambda \sigma_{t-1}^{2} ;
\end{aligned}
$$

where, $R_{t}^{\text {Index }}$ is our stock index return at time $t$, which is $R_{t}^{V N I}$ in the first model and $R_{t}^{H N X}$ in the second model. $R_{t-1}^{\text {Indicator }}$ includes the return of WTI oil price and the return of EUR to VND exchange rate at time $t-1$.

We report some important results in column 2 and 3 of Table 5. First, the impacts of WTI oil price return on the stock index returns are similar to that of the baseline results. The coefficient of $R_{W T I}$ is negative and statistically significant at $1 \%$ level in both $\mathrm{VN}$ index and HNX index regression models. Compare to the previous findings, the EUR to VND exchange rate return has statistically insignificant effects on both VN index and HNX index returns.

In term of the effect on stock index volatility, the results are different. In particular, the WTI oil price return only has a negative effect on $\mathrm{VN}$ index return volatility, and this effect is significant at $10 \%$ level. It has no significant correlation with the volatility of HNX-index. In addition, the correlations between the EUR/VND return and the volatility of stock index returnsis heterogeneous across $\mathrm{VN}$-index and HNX-index. Whilst an increase in EUR/VND predicts a decrease in volatility for $\mathrm{VN}$ index return, it has a positive effect on the volatility of HNX index.

Table 5 reports the robustness regression results of oil price and/or exchange rate effect on Viet Nam stock index. We report the results using different oil price and exchange rate, $\operatorname{EGARCH}(1,1)$ model and different sub-sample, i.e. post financial crisis, respectively. Panel A reports the coefficients and standard errors of the mean equation in (3), 
Table 5: Robustness tests

\begin{tabular}{|c|c|c|c|c|c|c|}
\hline \multirow{2}{*}{ Dependent variable } & \multicolumn{2}{|c|}{$\begin{array}{l}\text { Different oil price and } \\
\text { exchange rate }\end{array}$} & \multicolumn{2}{|c|}{ EGARCH $(1,1)$ model } & \multicolumn{2}{|c|}{$\begin{array}{l}\text { Post financial crisis 2007- } \\
2009\end{array}$} \\
\hline & $R_{t}^{V N I}$ & $R_{t}^{H N X}$ & $R_{t}^{V N I}$ & $R_{t}^{H N X}$ & $R_{t}^{V N I}$ & $R_{t}^{H N X}$ \\
\hline \multicolumn{7}{|c|}{ Panel A: Mean equation } \\
\hline$R_{t-1}^{V N I}$ & $0.4336^{* * *}$ & & $0.4432^{* * *}$ & & $0.3121^{* * *}$ & \\
\hline$R_{t-1}^{H N X}$ & & $0.2926^{* \star *}$ & & $0.2984^{\star * *}$ & & $0.2282^{* * *}$ \\
\hline $\begin{array}{l}\text { Oil price return } \\
R_{t-1}^{W T I} \text { or } R_{t-1}^{\text {Brent }}\end{array}$ & $0.0170^{* * *}$ & $0.0337^{* * *}$ & $0.0190^{* * *}$ & $0.0484^{\star \star \star}$ & $0.0500^{* * *}$ & $0.0387^{* * *}$ \\
\hline $\begin{array}{l}\text { Exchange rate return } \\
R_{t-1}^{E U R} \text { or } R_{t-1}^{U S}\end{array}$ & 0.0091 & 0.0162 & -0.0700 & -0.0561 & $-0.1411^{* *}$ & $-0.1053^{* *}$ \\
\hline Constant & $0.0003^{* * *}$ & $0.0006^{* * *}$ & $0.0003^{* * *}$ & $0.0004^{* * *}$ & $0.0005^{* * *}$ & $0.0005^{* * *}$ \\
\hline \multicolumn{7}{|c|}{ Panel B: Variance equation } \\
\hline$R_{t-1}^{W T I}$ & $-8.4576^{*}$ & -7.4872 & $-1.2297^{* * *}$ & $-1.3525^{* * *}$ & $-20.4050^{* * *}$ & $-14.1672^{* \star}$ \\
\hline$R_{t-1}^{E U R}$ & $-31.8536^{*}$ & $88.6229^{* * *}$ & 5.7164 & 5.9445 & $39.9110^{* * *}$ & $61.8700^{* * *}$ \\
\hline Constant & $-12.6459^{* * *}$ & $-12.6764^{* * *}$ & $-0.4373^{\star * *}$ & $-0.3320^{* * *}$ & $-12.0757^{* * *}$ & $-12.6690^{\star * *}$ \\
\hline
\end{tabular}

${ }^{*},{ }^{* *}$, and ${ }^{* * *}$ denote significance at the $10 \%, 5 \%$ and $1 \%$ levels, respectively.

while Panel B reports the coefficients and standard errors of the variance equation in (4). Note that all the ARCH and $\mathrm{GARCH}$ terms are significance at $1 \%$ level in all regressions. For EGARCH $(1,1)$ model reported in column 4 and 5, the EARCH, absolute EARCH and EGARCH terms are significance at $1 \%$ level in all regressions, except the EARCH term of the variance equation in $\mathrm{VN}$ index model I is significance at $5 \%$ level.

\subsubsection{Different Model}

One of the greatest weaknesses of the $\operatorname{GARCH}(1,1)$ model is that it cannot account for the asymmetric effects of positive and negative shocks. Therefore, to overcome this problem, we employ the EGARCH $(1,1)$ model.iii The regression model takes the following form:

$$
\begin{aligned}
& R_{t}^{\text {Index }}=\beta_{0}+\beta_{1} R_{t-1}^{\text {Index }}+\beta R_{t-1}^{\text {Indicator }}+\varepsilon_{t}, \varepsilon_{t} \rightarrow N\left(0, \sigma_{t}^{2}\right), \\
& \ln \left(\sigma_{t}^{2}\right)=\omega_{0}+\gamma \frac{\varepsilon_{t-1}}{\sigma_{t-1}}+\alpha\left|\frac{\varepsilon_{t-1}}{\sigma_{t-1}}\right|+\lambda \sigma_{t-1}^{2} ; \\
& R_{t}^{\text {Index }}=\beta_{0}+\varepsilon_{t}{ }^{\prime} \varepsilon_{t} \rightarrow N\left(0, \sigma_{t}^{2}\right) \\
& \ln \ln \left(\sigma_{t}^{2}\right)=\omega_{0}+\omega_{1} R_{t-1}^{\text {Indicator }}+\gamma \frac{\varepsilon_{t-1}}{\sigma_{t-1}}+\alpha\left|\frac{\varepsilon_{t-1}}{\sigma_{t-1}}\right|+\lambda \sigma_{t-1}^{2}
\end{aligned}
$$

where, $R_{t}^{\text {Index }}$ is our stock index return at time $t$, which is $R_{t}^{V N I}$ in the first model and $R_{t}^{H N X}$ in the second model. $R_{t-1}^{\text {Indicator }}$ includes the return of BRENT oil price and the return of USD to VND exchange rate at time $t-1$.

The regression results are presented in column 4 and 5 of Table 5. Consistent with the earlier results, BRENT oil price return is shown to have positive effect on stock market. An increase in oil price return helps to increase to stock market index returns and dampen the volatility of both $\mathrm{VN}$ index and HNX index. In contrast, the USD to VND exchange rate is shown to have no significant relationship with both stock returns and volatility.

\subsubsection{Different Sub-sample}

As we observe from the historical data, the period of high volatility for all variables coincides with the financial crisis 2007-2009. Therefore, to avoid the potential bias caused by the financial crisis, we re-estimate our $\operatorname{GARCH}(1,1)$ model again for the post-crisis period to see if our result is robust. A sub-sample that starts from January $1^{\text {st }} 2010$ and ends in October $25^{\text {th }} 2019$ is employed. The results are presented in column 6 and 7 of Table 5. Consistent with our main regression results, oil price return continues to positively impact on stock return and negative impact on stock index 
volatility. On the other hand, the USD/VND return shows opposite effects on stock market index and volatility.

\section{Conclusion}

This paper aims to test whether exchange rate and oil pricehave impacts on Vietnamese stock market return and volatility. We perform our analysis on the sample of daily data from August $1^{\text {st }} 2000$ to October $25^{\text {th }} 2019$. Due to the presence heteroskedasticity in our data, we use GARCH $(1,1)$ and EGARCH $(1,1)$ models to perform our analysis instead of the traditional OLS regression.

In summary, the results show that historical oil price has a significant positive effect on the two Vietnamese stock market indices, VN index and HNX index. In term of the stock index volatility, both the VN index and HNX index volatilities are negatively impacted by the return of oil price. On the other hand, exchange rate return exhibits negative effects on stock index returns and positive effect on the volatility of VN index and HNX index returns. We also employ some robustness tests, namely: (1) different oil price and exchange rate; (2) different model specification, i.e., $\operatorname{EGARCH}(1,1)$; and (3) different sub-sample. While the conclusion about the impact of oil price remained consistent through all three robustness tests, the effect of exchange rate on Vietnamese stock market indices is not stable. This suggests further research needs to be conducted on the relationship between exchange rate and Vietnamese stock market index.

\section{References}

Aggarwal, R. (1981). Exchange rates and stock prices: A study of the US capital markets under floating exchange rates. Akron Business and Economic Review, 12(3), 7-12.

Agrawal, G. (2010). A Study of Exchange Rates Movement and Stock Market Volatility. International Journal of Business and Management, 5(12). DOI:10.5539/ijbm.v5n12p62

Ajayi, R. A., \& Mougoue, M. (1996). On The Dynamic Relation Between Stock Prices And Exchange Rates. The Journal of Financial Research, 19(2), 193-207.

Aloui, C. (2007). Price and Volatility Spillovers between Exchange Rates and Stock Indexes for the Pre- and Post-Euro Period. Quantitative Finance, 7(6), 669-685.

Aloui, R., Hammoudeh, S., \& Nguyen, D. (2013). A time-varying copula approach to oil and stock market dependence: The case of transition economies. Energy Economics, 39, 208-221.

Basher, S. A., \& Sadorsky, P. (2006). Oil price risk and emerging stock markets. Global Finance Journal, 17(2), 224-251.

Chiang, T. C., Yang, S. Y., \& Wang, T. S. (2000). Stock Return and Exchange Rate Risk: Evidence from Asian Stock Markets
Based on A Bivariate GARCH Model. International Journal of Business, 5(2), 97-117.

Driesprong, G., Jacobsen, B., \& Maat, B. (2008). Striking oil: Another puzzle? Journal of Financial Economics, 89, 307-327.

Echchabi, A., \& Azouzi, D. (2017). Oil Price Fluctuations and Stock Market Movements: An Application in Oman. Journal of Asian Finance, Economics and Business, 4(2), 19-86. http:// dx.doi.org/10.13106/jafeb.2017.vol4.no2.19

Gay, R. D. (2008). Effect Of Macroeconomic Variables On Stock Market Returns For Four Emerging Economies: Brazil, Russia, India, And China. International Business \& Economics Research Journal, 7(3), 1-8.

Giovannini, A., \& Jorion, P. (1987). Interest rates and risk premia in the stock market and in the foreign exchange market. Journal of International Money and Finance, 6(1), 107-123.

Ibrahim, M. H., \& Aziz, H. (2003). Macroeconomic Variables and the Malaysian Equity Market. Journal of Economic Studies, 30, 6-27.

Jain, A., \& Biswal, P. (2016). Dynamic linkages among oil price, gold price, exchange rate, and stock market in India. Resources Policy, 49, 179-185.

Kang, W., de Gracia, F. P., \& Ratti, R. A. (2017). Oil price shocks, policy uncertainty, and stock returns of oil and gas corporations. Journal of International Money and Finance, 70, 344-359.

Kang, W., Ratti, R. A., \& Vespignani, J. (2016). The impact of oil price shocks on the U.S. stock market: A note on the roles of U.S. and non-U.S. oil production. Economics Letters, 145, 176181.

Kang, W., Ratti, R., \& Yoon, K. H. (2015). The impact of oil price shocks on the stock market return and volatility relationship. Journal of International Financial Markets, Institutions and Money, 34, 41-54.

Killian, L., \& Park, C. (2009). The impact of oil price shocks on the U.S. stock market. International Economic Review, 50, 12671287.

Kim, K.-h. (2003). Dollar exchange rate and stock price: evidence from multivariate cointegration and error correction model. Review of Financial Economics, 12, 301-313.

Kurihara, Y. (2006). The Relationship between Exchange Rate and Stock Prices during the Quantitative Easing Policy in Japan. International Journal of Business, 11(4), 375-386.

Lee, J. W., \& Brahmasrene, T. (2019). Long-run and Short-run Causality from Exchange Rates to the Korea Composite Stock Price Index. Journal of Asian Finance, Economics and Business, 6(2), 257-267. https://doi.org/10.13106/jafeb.2019. vol6.no2.257

Lee, J. W., \& Zhao, T. F. (2014). Dynamic Relationship between Stock Prices and Exchange Rates: Evidence from Chinese Stock Markets. Journal of Asian Finance, Economics and Business, 1(1), 5-14. https://doi.org/10.13106/jafeb.2014.vol1. no1.5. 
Miller, J., \& Ratti, R. (2009). Crude oil and stock markets: Stability, instability, and bubbles. Energy Economics, 31, 559-568.

Narayan, P. K., \& Narayan, S. (2010). Modelling the Impact of Oil Prices on Vietnam's Stock Prices. Applied Energy, 87, 356-361.

Nguyen, V. N., \& Nguyen, D. T. (2020). Can Crude Oil Price be a Predictor of Stock Index Return? Evidence from Vietnamese Stock Market. Asian Economic and Financial Review, 10(1), 13-21.

Nieh, C.-C., \& Lee, C.-F. (2001). Dynamic relationship between stock prices and exchange rates for G-7 countries. The Quarterly Review of Economics and Finance, 41(4), 477-490.

Olugbenga, A. A. (2012). Exchange Rate Volatility and Stock Market Behaviour: The Nigerian Experience. European Journal of Business and Management, 4(5), 31-39.

Park, J., \& Ratti, R. (2008). Oil price shocks and stock markets in the U.S. and 13 European countries. Energy Economics, 30, 2587-2608.

Phan, D., Sharma, S. S., \& Narayan, P. K. (2015). Intraday volatility interaction between the crude oil and equity markets. Journal of International Financial Markets, Institutions \& Money. 40, 1-13. https://doi.org/10.1016/j.intfin.2015.07.007

Smiech, S., \& Papiez, M. (2013). Fossil fuel prices, exchange rate, and stock market: A dynamic causality analysis on the European market. Economics Letters, 118, 199-202.

Walid, C., Chaker, A., Masood, O., \& Fry, J. (2011). Stock market volatility and exchange rates in emerging countries: A Markovstate switching approach. Emerging Markets Review, 12, 272-292.

Yang, S.-Y., \& Doong, S.-C. (2004). Price and Volatility Spillovers between Stock Prices and Exchange Rates: Empirical Evidence from the G-7 Countries. International Journal of Business and Economics, 3(2), 139-153.

Youssel, M., \& Mokni, K. (2019). Do Crude Oil Prices Drive the Relationship between Stock Markets of Oil-Importing and Oil-Exporting Countries? Economies, 7(3), 70. https://doi. org/10.3390/economies 7030070

Zhao, H. (2010). Dynamic relationship between exchange rate and stock price: Evidence from China. Research in International Business and Finance, 24, 103-112. 